\title{
Comparison of three common whole blood platelet function tests for in vitro P2Y12 induced platelet inhibition
}

\author{
Joao D. Dias ${ }^{1} \cdot$ Torben Pottgiesser $^{2} \cdot$ Jan Hartmann ${ }^{3} \cdot$ Daniel Duerschmied $^{2} \cdot$ Christoph Bode $^{2} \cdot$ Hardean E. Achneck $^{3}$
}

Published online: 16 October 2019

(c) The Author(s) 2019

\begin{abstract}
In the context of interventional cardiology, platelet function testing may identify patients treated with P2Y12-inhibitors at an increased risk of mortality, thrombosis and bleeding. Several whole blood point-of-care platelet function analyzers are available; however, inter-device differences have not been examined systematically. To compare three platelet function tests under standardized in vitro conditions. Healthy volunteer $(\mathrm{n}=10)$ blood samples were spiked with increasing concentrations of ticagrelor $(0-7500 \mathrm{ng} / \mathrm{mL})$ and/or ASA $(0-3280 \mathrm{ng} / \mathrm{mL})$, measured on three platelet function analyzers $\left(\mathrm{TEG}^{\circledR} 6 \mathrm{~s}\right.$, Multiplate $^{\circledR}$, and VerifyNow ${ }^{\circledR}$ ) and respective Effective Concentration (EC) levels EC10, EC50 and EC90 were calculated. Repeatability was assessed in a separate group of pooled blood samples $(\mathrm{n}=10)$ spiked with ticagrelor at EC10, EC50 and EC90. ASA had no impact on ADP-activated channels for all three devices. TEG ${ }^{\circledR} 6 \mathrm{~s}$ was able to distinguish $(\mathrm{p} \leq 0.05)$ between all ticagrelor EC zones; VerifyNow ${ }^{\circledR}$ and Multiplate ${ }^{\circledR}$ were able to distinguish between three and two zones, respectively. Multiplate ${ }^{\circledR}$ showed the largest window between EC10 and EC90 $(19-9153 \mathrm{ng} / \mathrm{mL})$, followed by TEG ${ }^{\circledR} 6 \mathrm{~s}(144-2589$ $\mathrm{ng} / \mathrm{mL})$, and VerifyNow ${ }^{\circledR}(191-1100 \mathrm{ng} / \mathrm{mL})$. Drug effect models distribution of disagreements were identified for TEG ${ }^{\circledR} 6 \mathrm{~s}$ (5.0\%), VerifyNow ${ }^{\circledR}(8.3 \%)$, and Multiplate ${ }^{\circledR}(13.3 \%)$. TEG $^{\circledR} 6 \mathrm{~s}$ showed the smallest average coefficient of variation between EC conditions (5.1\%), followed by Multiplate ${ }^{\circledR}(14.1 \%)$, and VerifyNow ${ }^{\circledR}(17.7 \%)$. Linear models could be generated between $\mathrm{TEG}^{\circledR} 6 \mathrm{~s}$ and Multiplate ${ }^{\circledR}$, but not VerifyNow ${ }^{\circledR}$. Significant differences were found between whole blood point-of-care platelet function analyzers and the clinical impact of these differences needs to be further investigated.
\end{abstract}

Keywords Coagulation $\cdot$ Diagnostic $\cdot \mathrm{TEG}^{\circledR} \cdot$ Platelet function $\cdot$ Platelets

\section{Highlights}

Joao D. Dias and Torben Pottgiesser have contributed equally to this work.

Electronic supplementary material The online version of this article (https://doi.org/10.1007/s11239-019-01971-1) contains supplementary material, which is available to authorized users.

Joao D. Dias

jdias@haemonetics.com

Haemonetics S.A., Signy, Switzerland

2 Department of Cardiology and Angiology I, Faculty of Medicine, Heart Center Freiburg University, University of Freiburg, Freiburg, Germany

3 Haemonetics Corporation, Braintree, USA
- Platelet function devices have different measurement scales and so there is a lack of information comparing their performance under controlled conditions.

- Significant differences were found between three whole blood point-of-care platelet function analyzers.

- The $\mathrm{TEG}^{\circledR} 6 \mathrm{~s}$ analyzer was shown to have the highest degree of repeatability with the lowest level of disagreement between duplicate measurements.

- There is a need to develop and validate standardized cutoff values for these platelet function analyzers in order to find the optimal range of platelet reactivity. 


\section{Introduction}

Dual antiplatelet therapy (DAPT) consisting of acetylsalicylic acid (ASA) and a P2Y12 receptor blocker is recommended to reduce platelet reactivity and prevent thrombotic events after percutaneous coronary intervention (PCI) [1]. DAPT, however, is also associated with increased risk of bleeding as compared with treatment with a single platelet inhibitor and further increased with the potency of the combination partner [2]. Platelet function testing can be utilized to monitor therapy with P2Y12inhibitors and identify low (LPR) and high (HPR) platelet reactivity during therapy [3]. In several consensus documents, cut-off values for LPR and HPR were extrapolated from the results of several clinical trials and linked to a higher risk of mortality and stent thrombosis (HPR) or an elevated risk for bleeding (LPR) [3, 4].

According to current revascularization guidelines (Class IIb recommendation), platelet function testing may be considered to de-escalate DAPT in patients with acute coronary syndrome; particularly in those deemed unsuitable for maintained potent platelet inhibition over 12 months [1, 5]. Furthermore, platelet function testing may be considered to guide the timing of cardiac surgery in patients who have recently received $\mathrm{P} 2 \mathrm{Y} 12$ inhibitors $[1,6]$.

Several whole blood platelet function assessment devices that can be used in a near-patient set up are commercially available. Thromboelastography $\left(\right.$ TEG $\left.^{\circledR}\right)(\mathrm{Hae}-$ monetics, Braintree, MA, USA), Multiplate ${ }^{\circledR}$ (Roche Diagnostics, Rotkreuz, Switzerland), PFA-100/PFA-200 (Siemens, Munich, Germany) and VerifyNow ${ }^{\circledR}$ (Accumetrics, San Diego, CA, USA) systems are the most frequently studied. TEG ${ }^{\circledR}$ PlateletMapping ${ }^{\circledR}$ has been shown to be predictive of bleeding and thrombotic risk in patients undergoing PCI [7, 8], cardiac [9-11], and non-cardiac surgery $[11,12]$; and the TEG ${ }^{\circledR}$ DOAC cartridge can detect and classify direct oral anticoagulants with high specificity and sensitivity [13]. The clinical value of Multiplate ${ }^{\circledR}$ in patients undergoing PCI or cardiac surgery [14-16], and VerifyNow ${ }^{\circledR}$ in patients undergoing cardiac surgery [17, $18]$ has also been established.

Light transmission aggregometry (LTA) is a traditional platelet function test, but is poorly standardized and unlikely to be widely used in clinical practice [19]. Flow cytometry analyzes the functional status of platelets in vivo; specifically, it evaluates intracellular transduction. The efficacy of antiplatelet drugs can be monitored with flow cytometry through the intracellular quantification of Vasodilator Stimulated Phosphoprotein (VASP) phosphorylation [19].

Platelet function devices have different measurement scales and so there is a lack of information comparing their performance under controlled conditions. This is despite recommendations to perform platelet function testing to assess and manage bleeding and thrombosis, and the consensus-defined, uniform cut-offs for standardized platelet function assays [3]. In this study, we compared adenosine di-phosphate (ADP) tests (PlateletMapping ${ }^{\circledR}$ ADP, Multiplate ${ }^{\circledR}$-ADP and the VerifyNow ${ }^{\circledR}$ P2Y 12 Platelet Reactivity Test [P2Y12-PRU]) for their performance and correlation of results in response to antiplatelet inhibition in healthy volunteer blood samples spiked with ticagrelor and/or ASA.

\section{Materials and methods}

\section{Study design}

Blood samples were drawn from healthy donors, in accordance with ISO 17025 and Good Laboratory Practices (GLP). This study was conducted in two stages: the first study assessed the concentration dependent effects of ticagrelor and ASA on platelet function measurements obtained with the three analyzers $\left(\mathrm{TEG}^{\circledR} 6 \mathrm{~s}\right.$, Multiplate ${ }^{\circledR}$, and VerifyNow ${ }^{\circledR}$ ), while the second study evaluated the repeatability of measurement with each analyzer at fixed concentrations.

\section{Platelet function tests}

\section{TEG ${ }^{\circledast 6 s}$}

The TEG ${ }^{\circledR} 6 \mathrm{~s}$ hemostasis analyzer is a fully automated diagnostic instrument, employing a four channel cartridge system to quantify the viscoelastic properties of a whole blood clot from the enzymatic phase through to the fibrinolytic phase [20-22]. Four independent assays are conducted to provide a comprehensive overview of the patients' coagulation status (citrated kaolin [CK], citrated kaolin with heparinase $[\mathrm{CKH}]$, citrated rapidTEG ${ }^{\circledR}[\mathrm{CRT}]$, and citrated functional fibrinogen $[\mathrm{CFF}])$. The PlateletMapping ${ }^{\circledR}$ cartridge allows selective activation of the P2Y12 receptor by ADP or through the thromboxane pathway using ASA.

\section{Multiplate $^{\circledast}$}

The Multiplate ${ }^{\circledR}$ analyzer is a semi-automated point-of-care (POC) device using a five channel computerized system to perform multiple electrode impedance aggregometry in whole blood. Two independent sensor units detect impedance and automatically calculate area under the curve. Several activators are available, exploring different pathways of platelet activation in a similar process to LTA [23-25]. 


\section{VerifyNow ${ }^{\oplus}$}

VerifyNow ${ }^{\circledR}$ is a POC, turbidimetric-based optical detection device that provides a quantitative measure of platelet aggregation in whole blood [26]. This system provides two assays, each sensitive to targeted drugs. The aspirin assay is sensitive to ASA and utilizes arachidonic acid as an agonist [19]. The P2Y12 assay is sensitive to thienopyridines and uses ADP as an agonist and prostaglandin E1 (PGE1) as a suppressor of intracellular free calcium levels to reduce the nonspecific contribution of ADP binding to P2Y1 receptors [19]. Platelet aggregation results obtained from the VerifyNow ${ }^{\circledR} \mathrm{P} 2 \mathrm{Y} 12$ assay are similar to those obtained with traditional LTA techniques [23, 27, 28].

\section{Study 1: concentration dependent effects of platelet aggregation inhibitors}

Whole blood samples from 10 healthy volunteers were drawn using a three-step phlebotomy process to maintain the stability of thrombocytes. The maximum total blood draw per donor was $209 \mathrm{~mL}$, and samples were collected using one of three blood tube types; $6 \mathrm{~mL}$ BD Vacutainer ${ }^{\circledR}$ LithiumHeparin tubes $\left(\mathrm{TEG}^{\circledR} 6 \mathrm{~s}\right.$ ), $3 \mathrm{~mL}$ Hirudin tubes (Multiplate ${ }^{\circledR}$ ), or $2 \mathrm{~mL}$ Greiner Bio-One partial-fill VACUETTE ${ }^{\circledR}$ tubes with $3.2 \%$ sodium-citrate $\left(\right.$ VerifyNow $\left.^{\circledR}\right)$. After each phlebotomy, the samples were equilibrated at room temperature for $30 \mathrm{~min}$, before pooling the collected samples per patient for each blood tube type. The samples were then spiked $(1: 10)$ and incubated for $10 \mathrm{~min}$ before the start of analysis. Three blood draws were performed at 90-min intervals, and analyzed at the time of sampling. Samples for each run were spiked with six concentrations of ticagrelor $(0-7500$ $\mathrm{ng} / \mathrm{mL})$ in addition to ASA $(0-3260 \mathrm{ng} / \mathrm{mL})$; these doses were selected to represent prescribed drug regimens. This resulted in 18 drug combinations, generated in duplicate per donor for each of the three analyzers, for a total of 108 samples per donor. Details of the stock solution preparation and experiments to determine the appropriate final concentration of 1\% DMSO (Supplementary Fig. 1) can be found in supplementary materials.

To analyze platelet function in the prepared samples, the PlateletMapping ${ }^{\circledR}$-ADP test was performed for the TEG ${ }^{\circledR} 6 \mathrm{~s}$, the ADP test for the Multiplate ${ }^{\circledR}$ analyzer, and the P2Y12PRU for the VerifyNow ${ }^{\circledR}$ system. All assays were performed in line with the operational procedures detailed in the manual for each analyzer.

\section{Study 2: variability of the platelet function devices}

Whole blood samples from 10 healthy volunteers were collected as described above; the maximum total blood draw per donor was $87 \mathrm{~mL}$. This study compared the three devices to assess variability at Effective Concentration levels EC10, EC50, and EC90. Firstly, whole blood samples from 10 healthy donors without ticagrelor and ASA were tested with TEG ${ }^{\circledR} 6 \mathrm{~s}$, Multiplate ${ }^{\circledR}$ and VerifyNow ${ }^{\circledR}$ systems in a single measurement. Samples were drawn from each donor and collected in the same three blood tube types as Study 1 , with one blood tube of each type collected per donor and per phlebotomy. Secondly, pooled blood samples from 10 healthy donors were spiked with ticagrelor 10-15 min before measurement start, at EC10, EC50, and EC90 (Supplementary Table 1), and measured 10 times on each device. Working solutions of ticagrelor for spiking blood samples were prepared as described in the supplementary methods. Platelet function analysis of the prepared blood samples was conducted using the same tests per analyzer as detailed for Study 1.

\section{Statistical analysis}

Descriptions of the visual analysis and modeling framework methods can be found in Supplementary Methods.

\section{Results}

\section{Donor demographics}

In total, 21 volunteers were enrolled in these studies; 11 volunteers participated in study 1 , and ten volunteers in study 2. Overall, study participants (38\% female/62\% male) were healthy and currently receiving no medication, Caucasian, and had an average age of 39 years (range 19-57 years). In Study $1,73 \%$ of the participants were male, with an average age of 45 years (range 20-57 years), and in Study 2, 50\% of participants were male, with an average age of 32 years (range 19-49 years).

\section{Study 1: concentration dependent effects of platelet aggregation inhibitors}

Drug effect curve models were successfully generated for each device (Supplementary Fig. 2). No ASA impact in the ADP-activated channels was observed, as confirmed by the $\mathrm{p}$-values obtained by t-test for the three different regions of the dependent variable (Supplementary Table 2). There was no significant difference in the level of platelet aggregation inhibition across the three concentrations of ASA ( $p>0.1)$. Similar results were seen across all three devices; therefore, ASA was not utilized in any further spiking experiments.

The Effective Concentrations of ticagrelor (EC10, EC50, and EC90) were determined for each analyzer and the ability of each device to distinguish between four drug zones (<EC10, EC10-EC50, EC50-EC90, >EC90) was 
Table 1 Effective dose calculations for ticagrelor

\begin{tabular}{llll}
\hline & EC10 & EC50 & EC90 \\
\hline TEG $^{\circledR} 6 \mathrm{~s}$-MA & $144[-14,301]$ & $517[24,1010]$ & $2589[-3734,8912]$ \\
Multiplate $^{\circledR}$-AU & $19[-6,43]$ & $176[18,334]$ & $9153[-14511,32818]$ \\
VerifyNow $^{\circledR}$-PRU & $191[124,258]$ & $431[246,615]$ & $1100[149,2050]$ \\
\hline
\end{tabular}

Values given as $\mathrm{ng} / \mathrm{mL}$ (with confidence interval)

$A U$ aggregation in aggregation units, $E C$ effective concentration, $M A$ maximum amplitude, $P R U$ P2Y12 reaction units measured (Table 1 and Fig. 1 ). The TEG ${ }^{\circledR} 6 \mathrm{~s}$ was the only device able to distinguish between all four zones $(p<0.05)$. VerifyNow ${ }^{\circledR}$ systems were able to distinguish between three drug zones, $<$ EC10, EC50-EC90, and $>$ EC90 (p $\leq 0.05)$, while Multiplate ${ }^{\circledR}$ was able to distinguish between zones EC50-EC90 and > EC90 ( $<<0.05)$ (Supplementary Table 3). Multiplate ${ }^{\circledR}$ showed the largest window between EC10 and EC90 (19-9153 ng/mL), followed by TEG ${ }^{\circledR} 6 \mathrm{~s}$ $(144-2589 \mathrm{ng} / \mathrm{mL})$; VerifyNow ${ }^{\circledR}$ showed the smallest window (191-1100 ng/mL) (Table 1).

Distribution of disagreements were identified in the drug effect models for TEG $^{\circledR} 6 \mathrm{~s}(5.0 \%)$, VerifyNow ${ }^{\circledR}(8.3 \%)$, and Multiplate $^{\circledR}(13.3 \%)$.

\section{Study 2: variability of the platelet function devices}

The variability between measurements was evaluated for each device (Fig. 2). Mean (SD) of the measurements was -0.72 (3.31) $\mathrm{mm}$ for $\mathrm{TEG}^{\circledR} 6 \mathrm{~s}, 5.55$ (9.68) $\mathrm{AU}$ for Multiplate $^{\circledR}$, and -6.97 (20.59) PRU for VerifyNow ${ }^{\circledR}$. $\mathrm{TEG}^{\circledR} 6 \mathrm{~s}$ showed the smallest average coefficient of variation between EC conditions (5.1\%), followed by Multiplate ${ }^{\circledR}$ $(14.1 \%)$, and VerifyNow ${ }^{\circledR}(17.7 \%)$ (Table 2). The data was also scaled based on the device-specific EC50 window and $\mathrm{TEG}^{\circledR} 6 \mathrm{~s}$ still showed the smallest coefficient of variability (50.6\%), followed by VerifyNow ${ }^{\circledR}(61.2 \%)$, and Multiplate ${ }^{\circledR}$ (72.8\%) (Supplementary Table 4). Based on the device performance data agreement, linear models could be generated between TEG $^{\circledR} 6 \mathrm{~s}$ and Multiplate ${ }^{\circledR}$, but not VerifyNow ${ }^{\circledR}$ (Supplementary Table 5).

\section{Discussion}

For this comparison, an in vitro model of thienopyridine sensitive platelet function inhibition was utilized. Whole blood samples spiked with ticagrelor at doses equivalent to prescribed drug regimens, were tested for platelet function inhibition using three commercially available platelet function devices. The results presented here demonstrate that the TEG ${ }^{\circledR} 6 \mathrm{~s}$ and Multiplate ${ }^{\circledR}$ devices have consistent, interchangeable results. In contrast, high variability was seen between results from the $\mathrm{TEG}^{\circledR} 6 \mathrm{~s}$ and Multiplate ${ }^{\circledR}$ devices with the VerifyNow ${ }^{\circledR}$ device, meaning these results could not be correlated using a linear model. The TEG ${ }^{\circledR} 6 s$ analyzer was shown to have the highest degree of repeatability with the lowest level of disagreement between duplicate measurements. Multiplate ${ }^{\circledR}$ had the highest average variance between repeat measurements, and VerifyNow ${ }^{\circledR}$ had the lowest level of repeatability under device normalized conditions.

This is the first study comparing TEG $^{\circledR} 6 \mathrm{~s}$, Multiplate ${ }^{\circledR}$ and VerifyNow ${ }^{\circledR}$ under standardized conditions and at device normalized drug concentrations. By normalizing the study conditions to the device, we have been able to perform a clinically relevant comparison between devices despite the varying scales and movement patterns. VerifyNow ${ }^{\circledR}$ was found to have the narrowest window between EC10 and EC90 $(191 \mathrm{ng} / \mathrm{mL}$ and $1100 \mathrm{ng} / \mathrm{mL})$, which is equivalent to a $60 \mathrm{mg}$ ticagrelor pill (EC10) and close to the normal maximum blood concentration for $180 \mathrm{mg}$ ticagrelor (a dose of two $90 \mathrm{mg}$ pills) (EC90). Furthermore, we have shown that the VerifyNow ${ }^{\circledR}$ device had a high coefficient of variation (>20\%), particularly in the important drug ranges of EC50 and EC90. A potential benefit of this narrowest window performance to ticagrelor is a lower influence of measurement timing relative to when the last ticagrelor dose was taken. This also would suggest that $\mathrm{TEG}^{\circledR} 6 \mathrm{~s}$ and Multiplate ${ }^{\circledR}$ may be more sensitive to the peak and trough effects observed with pharmacodynamic measurements in the setting of ticagrelor use. Several studies using the VerifyNow ${ }^{\circledR}$ device to guide therapy in clinical settings have shown no significant improvement in patient outcomes [29-31]. This may be due to study design; additionally, it has previously been reported that VerifyNow ${ }^{\circledR}$ may overestimate the therapeutic response to clopidogrel in some individuals, potentially due to the utilization of PGE1 in addition to ADP [32]. This is in line with the results of our study, where low interchangeability of VerifyNow ${ }^{\circledR}$ results were seen with TEG ${ }^{\circledR} 6 \mathrm{~s}$ and Multiplate ${ }^{\circledR}$ results, and is further confirmed by a previous study noting poor agreement between VerifyNow ${ }^{\circledR}$ and Multiplate ${ }^{\circledR}$ [33].

The ability of TEG ${ }^{\circledR}$ PlateletMapping ${ }^{\circledR}$ to identify statistically significant platelet inhibition following antiplatelet therapy has previously been described [34]. Overestimation of platelet aggregation inhibition by ASA has been reported for VerifyNow ${ }^{\circledR}$ and Multiplate ${ }^{\circledR}$ [35]. However, in our study, there was no interference from ASA on ADP-induced 
Fig. 1 Effective dose analysis for ticagrelor. Graphs show fitted model plots for a TEG ${ }^{\circledR}, \mathbf{b}$ Multiplate $^{\circledR}$, and c VerifyNow ${ }^{\circledR}$ against $\log$ (ticagrelor). Black line represents the model curve, purple, red, and yellow lines represent EC10, EC50, and EC90, respectively. $M A$ maximum amplitude, $A U$ aggregation in aggregation units, $P R U$ P2Y12 reaction units
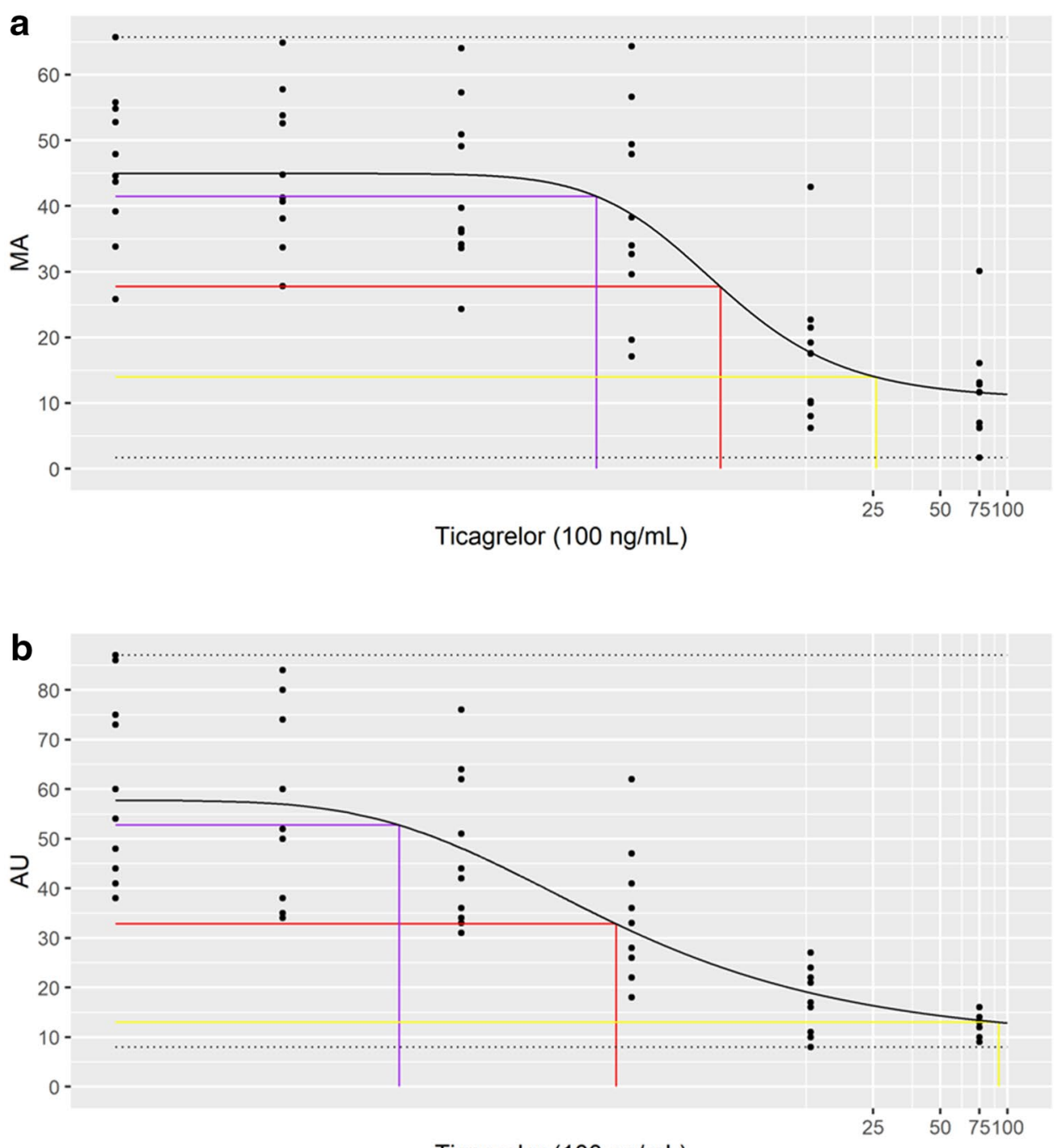

Ticagrelor $(100 \mathrm{ng} / \mathrm{mL})$

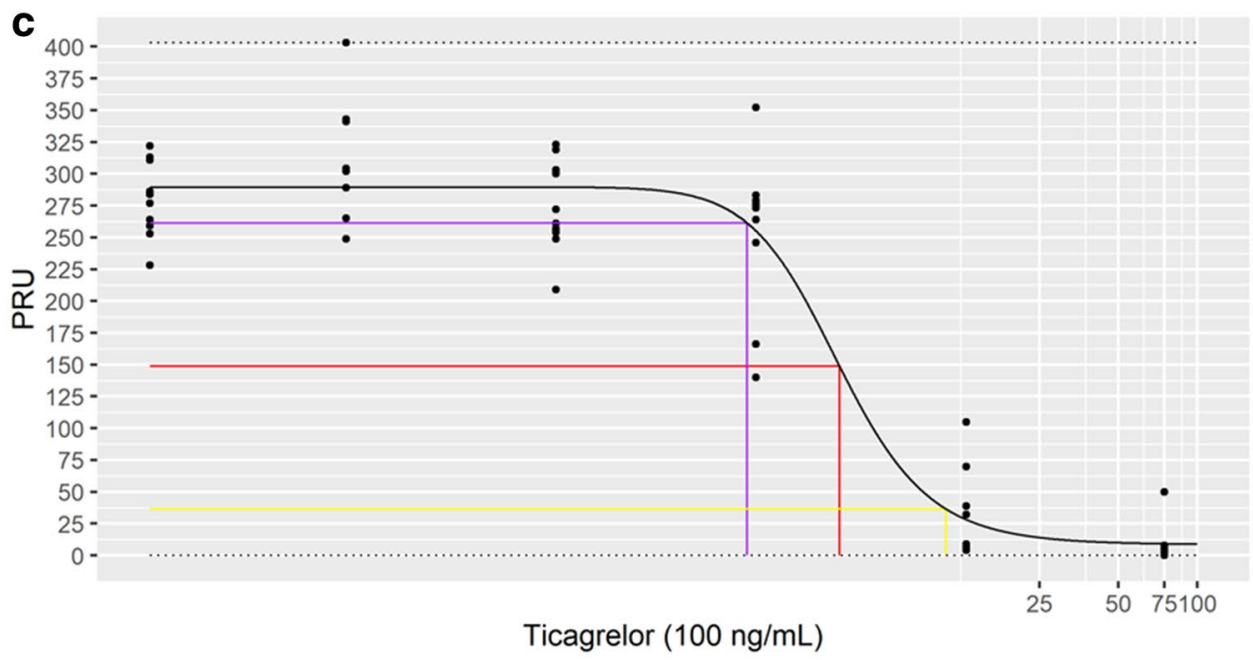


Fig. 2 Device variability analysis for $\mathbf{a}$ unscaled data, and $\mathbf{b}$ data scaled to EC50. The plots show the difference between measurements versus the mean of measurements. Blue lines show minimum and maximum values with respective confidence intervals, red lines show the average value with confidence interval

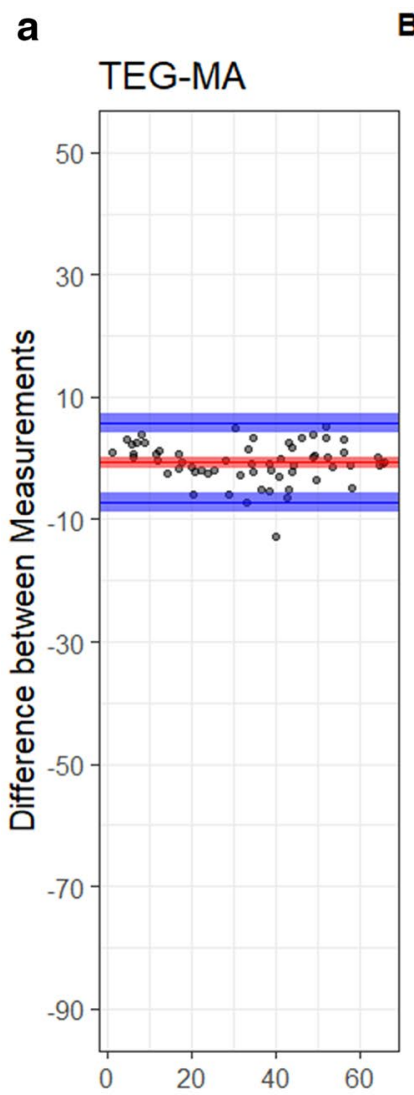

Bland-Altman Plots (Aspirin=0)
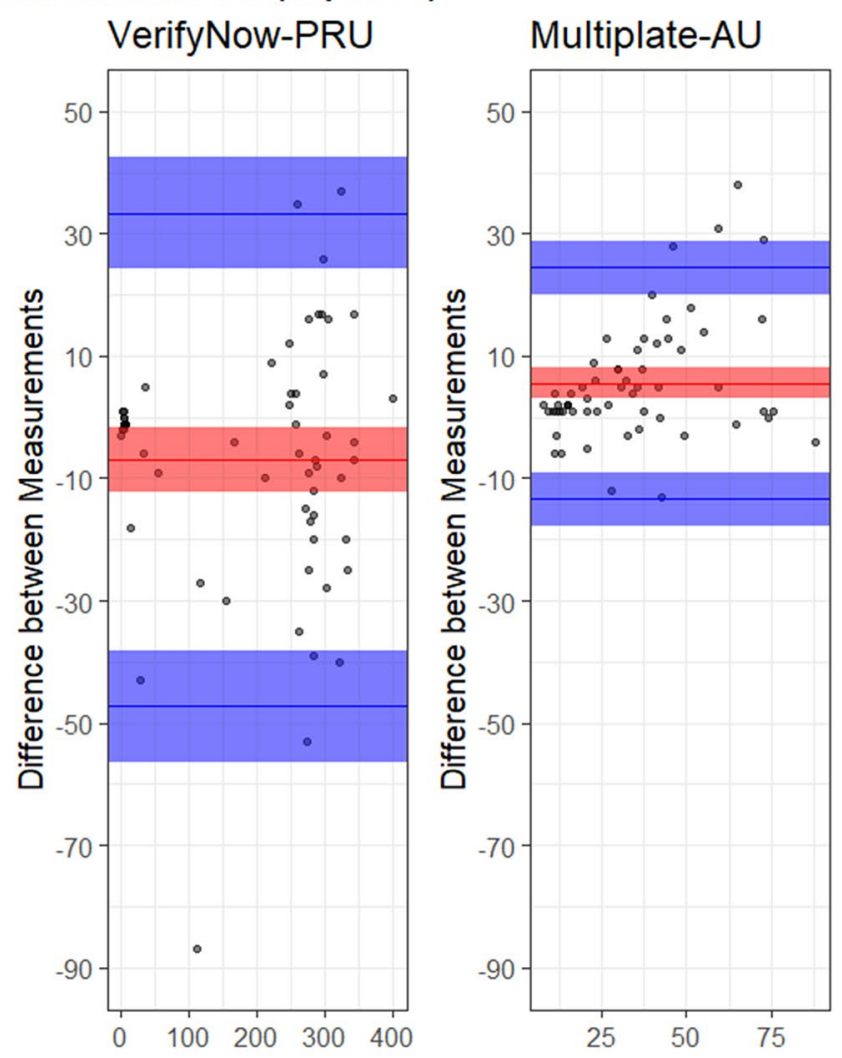

b

Bland-Altman Plots (Aspirin=0)

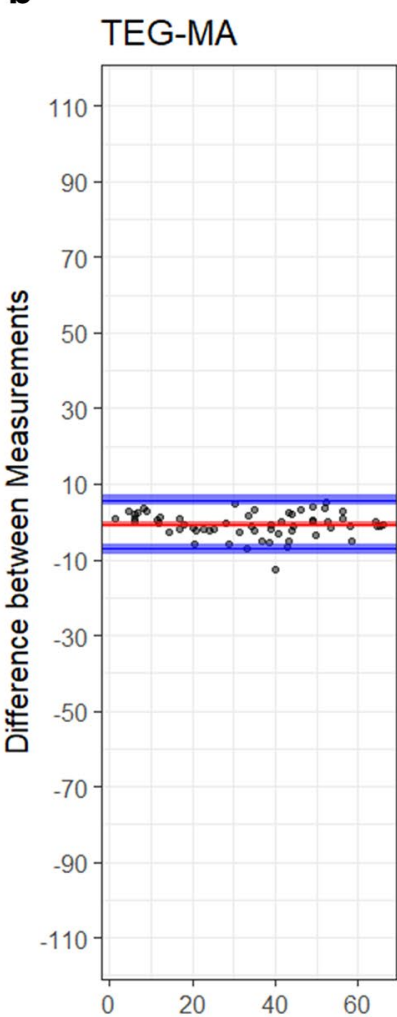

\section{VerifyNow-PRU}

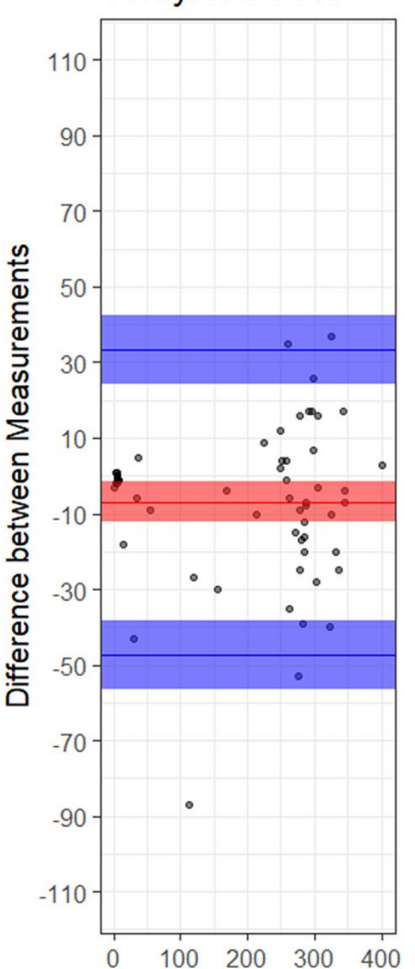

\section{Multiplate-AU}

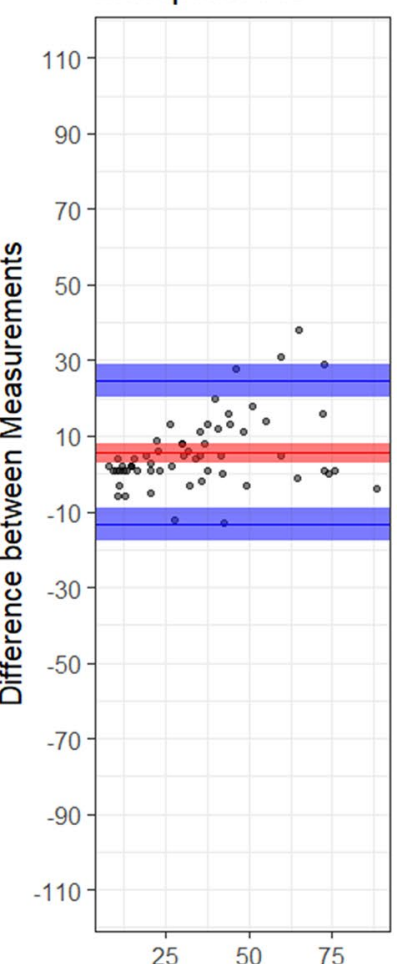


Table 2 Summary statistics for variability assessment of each device (data not scaled)

\begin{tabular}{|c|c|c|c|c|c|c|c|}
\hline & Mean & Median & SD & $\mathrm{CV}(\%)$ & MAD & LOO Mean & $\begin{array}{l}\text { Average } \\
\text { of CV } \\
(\%)\end{array}$ \\
\hline EC10_TEG ${ }^{\circledR} 6 \mathrm{~s}$ & 49.0 & 49.4 & 1.5 & 3.0 & 1.7 & 2.8 & 5.1 \\
\hline EC50_TEG ${ }^{\circledR} 6 \mathrm{~s}$ & 45.1 & 45.2 & 3.1 & 6.8 & 1.9 & 7.4 & \\
\hline EC90_TEG ${ }^{\circledR} 6 \mathrm{~s}$ & 10.6 & 10.7 & 0.6 & 5.6 & 0.4 & 1.4 & \\
\hline EC10_Multiplate ${ }^{\circledR}$ & 22.5 & 22.0 & 3.0 & 13.3 & 3.0 & 5.0 & 14.1 \\
\hline EC50_Multiplate ${ }^{\circledR}$ & 17.1 & 17.0 & 1.9 & 10.8 & 3.0 & 3.2 & \\
\hline EC90_Multiplate ${ }^{\circledR}$ & 15.4 & 15.5 & 2.8 & 18.2 & 1.5 & 5.1 & \\
\hline EC10_VerifyNow ${ }^{\circledR}$ & 234.6 & 237.5 & 21.7 & 9.2 & 27.4 & 40.7 & 17.7 \\
\hline EC50_VerifyNow ${ }^{\circledR}$ & 156.6 & 156.5 & 33.0 & 21.1 & 46.0 & 55.1 & \\
\hline EC90_VerifyNow ${ }^{\circledR}$ & 6.6 & 7.0 & 1.5 & 22.8 & 1.5 & 2.9 & \\
\hline
\end{tabular}

$C V$ coefficient of variability, $E C$ effective concentration, $L O O$ leave-one-out, $M A D$ mean absolute deviation, $S D$ standard deviation platelet aggregation at routine prescribed doses for DAPT; this is in line with other studies using multiple electrode aggregometry to evaluate dual platelet inhibition [36].

Several studies have found that the platelet function analyzers assessed here can give variable results when defined cut-off values are used to predict clinical outcomes [37, 38]. Published cut-off data for $\mathrm{TEG}^{\circledR} 6 \mathrm{~s}$ and Multiplate ${ }^{\circledR}$ were found to be interchangeable during this study, but the cut-off values for VerifyNow ${ }^{\circledR}$ were not. The proposed cutoff values described in this study were selected from measurements in sufficiently large patient populations, meaning that interpatient variability and test variability are already present and accounted for in the cut-off selection analysis. Contrary to the results described here, a study comparing $\mathrm{TEG}^{\circledR}$ with multiple electrode impedance aggregometry reported that while the $\mathrm{TEG}^{\circledR}$ PlateletMapping ${ }^{\circledR}$ assay was predictive of bleeding, Multiplate ${ }^{\circledR}$-ADP had a limited ability to predict transfusion requirements in cardiovascular surgery [10]. This disagreement with our results could potentially be explained by differences in the coefficient of variation between these two devices. Indeed, when we conducted the assessment using device-scaled conditions, Multiplate ${ }^{\circledR}$ displayed the highest coefficient of variability. Despite the collaborative analysis attempt towards clinical validation of cut-off points for platelet function testing in a large sample of patients undergoing PCI [3], our results clearly identify the need to develop standardized cut-off values for these platelet function analyzers in order to find the optimal range of platelet reactivity discriminating bleeding and ischemia with the lowest rates of adverse events as proposed by the consensus document [3].

To our knowledge, this is the first time an ex vivo model has been described to test platelet function devices at clinically relevant concentrations of P2Y12 inhibitors in human whole blood. A previous study used TEG $^{\circledR}$ and Multiplate ${ }^{\circledR}$ to assess the efficacy of hemostatic agents to improve hemostasis in vitro in ticagrelor-spiked blood samples; however, the ticagrelor concentrations used were not equivalent to prescribed dose regimens [39].

This study had several limitations, including that this was an in vitro experiment using blood samples from healthy human volunteers who do not represent the target population; however, this allowed for comparison of the platelet function analyzers under clearly defined, well-controlled conditions. Another limitation is that there is still some overlap between distributions of TEG ${ }^{\circledR} 6 \mathrm{~s}$ measurements over different ticagrelor concentrations due to the small sample size and DMSO usage. Once more data is collected, the hierarchical variability of measurements for the various concentrations of ticagrelor are expected to converge. Although it is difficult to draw clinical conclusions from this in vitro study, the data presented demonstrates that the $\mathrm{TEG}^{\circledR} 6 \mathrm{~s}$ device produces consistent, interchangeable results and that it is therefore a useful tool for monitoring platelet function. Confirming the clinical utility of the TEG ${ }^{\circledR} 6$ s device is an important future direction and this could include in vivo testing and additional comparisons with other platelet function tests such as VASP. Another area of interest to explore in future studies, would be to examine how the therapeutic window and cut-offs for each assay relate to thrombosis and bleeding risk. This analysis was not carried out in the current study, as patient data on bleeding and thrombosis was not available. However this analysis would be beneficial for future studies in order to demonstrate the clinical utility of these assays in monitoring the effect of drugs in reducing thrombosis risk. Other potential limitations of the study include manipulation of samples in vitro that may introduce additional variability not present in unaltered blood samples from patients taking antiplatelet therapy, and the addition of DMSO that may have had an impact on platelet function and may adversely affect repeatability. However, our overall results were in line with previously published work where $>1000$ fold ticagrelor dosing was required due to the reduced solubility when not including DMSO [39]. For this study, we were able to 
use dosing equivalent to the prescribed dosing regimen for these drugs.

There are several platelet aggregation inhibitors used frequently for DAPT; however, ticagrelor was the only platelet aggregation inhibitor used in these experiments, as ASA was found not to interfere with the inhibition of platelet aggregation. As ticagrelor is a reversible $\mathrm{P} 2 \mathrm{Y} 12$ receptor inhibitor, the results cannot be extended to the thienopyridine class of P2Y12 inhibitors including clopidogrel and prasugrel.

\section{Conclusion}

In this study, results from the analyzers $\mathrm{TEG}^{\circledR} 6 \mathrm{~s}$ and Multiplate ${ }^{\circledR}$ could be correlated but not with those from VerifyNow ${ }^{\circledR}$. Significant differences of repeatability and consistency of results were found between the different analyzers and the clinical impact of these differences in patient outcomes need to be further investigated in clinical trials.

Despite the collaborative analysis attempt towards clinical validation of standardized cut-off points for platelet function testing [3], there is a need to systematically develop standardized cut-off values for these platelet function analyzers in order to find the optimal range of platelet reactivity with validation in a randomized controlled trial enabling personalized antiplatelet therapy.

Acknowledgements The authors thank Meridian HealthComms, Plumley, UK for providing medical writing support, which was funded by Haemonetics SA, Signy, Switzerland in accordance with Good Publication Practice (GPP3). The authors also thank Clinstatdevice LLC, Lexington, MA, USA for providing biostatistics support, which was funded by Haemonetics Corp., Braintree, MA, USA. Finally, the authors would like to thank Elmar R. Burchardt MD, PhD for his comments on this work.

Author contributions JD, JH, and HA, conceived and designed the study. TP, DD and CB contributed to analysis and interpretation of data, drafting, and revising the manuscript. All authors revised the manuscript for important intellectual content and approved the final version for submission.

Conflict of interest JD, JH, and HA were employees of Haemonetics Corporation at the time of the study. This study was supported by Haemonetics Corporation (Braintree, Massachusetts). The authors have no other relevant financial interest in the products or companies described in this article. The corresponding author confirms he had full access to the data in the study and has final responsibility for the decision to submit for publication. TP, DD and CB did not receive any funding or consulting fee related to this project.

Open Access This article is distributed under the terms of the Creative Commons Attribution 4.0 International License (http://creativeco mmons.org/licenses/by/4.0/), which permits unrestricted use, distribution, and reproduction in any medium, provided you give appropriate credit to the original author(s) and the source, provide a link to the Creative Commons license, and indicate if changes were made.

\section{References}

1. Neumann FJ, Sousa-Uva M, Ahlsson A et al (2019) 2018 ESC/ EACTS Guidelines on myocardial revascularization. EuroIntervention 14(14):1435-1534

2. Wallentin L, Becker RC, Budaj A et al (2009) Ticagrelor versus clopidogrel in patients with acute coronary syndromes. N Engl J Med 361(11):1045-1057

3. Aradi D, Kirtane A, Bonello L et al (2015) Bleeding and stent thrombosis on P2Y12-inhibitors: collaborative analysis on the role of platelet reactivity for risk stratification after percutaneous coronary intervention. Eur Heart J 36(27):1762-1771

4. Tantry US, Bonello L, Aradi D et al (2013) Consensus and update on the definition of on-treatment platelet reactivity to adenosine diphosphate associated with ischemia and bleeding. J Am Coll Cardiol 62(24):2261-2273

5. Sibbing D, Aradi D, Jacobshagen C et al (2017) Guided deescalation of antiplatelet treatment in patients with acute coronary syndrome undergoing percutaneous coronary intervention (TROPICAL-ACS): a randomised, open-label, multicentre trial. Lancet 390(10104):1747-1757

6. Malm CJ, Hansson EC, Akesson J et al (2016) Preoperative platelet function predicts perioperative bleeding complications in ticagrelor-treated cardiac surgery patients: a prospective observational study. Br J Anaesth 117(3):309-315

7. Gurbel PA, Bliden KP, Guyer K et al (2005) Platelet reactivity in patients and recurrent events post-stenting: results of the PREPARE POST-STENTING Study. J Am Coll Cardiol 46(10):1820-1826

8. Gurbel PA, Bliden KP, Navickas IA et al (2010) Adenosine diphosphate-induced platelet-fibrin clot strength: a new thrombelastographic indicator of long-term poststenting ischemic events. Am Heart J 160(2):346-354

9. Mahla E, Suarez TA, Bliden KP et al (2012) Platelet function measurement-based strategy to reduce bleeding and waiting time in clopidogrel-treated patients undergoing coronary artery bypass graft surgery: the timing based on platelet function strategy to reduce clopidogrel-associated bleeding related to CABG (TARGET-CABG) study. Circ Cardiovasc Interv 5(2):261-269

10. Sivapalan P, Back AC, Ostrowski SR, Ravn HB, Johansson PI (2017) Transfusion requirements in elective cardiopulmonary bypass surgery patients: predictive value of Multiplate and Thromboelastography (TEG) Platelet Mapping Assay. Scand J Clin Lab Invest 77(5):345-351

11. Dias JD, Sauaia A, Achneck HE, Hartmann J, Moore EE (2019) Thromboelastography-guided therapy improves patient blood management and certain clinical outcomes in elective cardiac and liver surgery and emergency resusCitation: a systematic review and analysis. J Thromb Haemost 17:984-994

12. Kasivisvanathan R, Abbassi-Ghadi N, Kumar S et al (2014) Risk of bleeding and adverse outcomes predicted by thromboelastography platelet mapping in patients taking clopidogrel within 7 days of non-cardiac surgery. Br J Surg 101(11):1383-1390

13. Dias JD, Lopez-Espina CG, Ippolito J (2019) Rapid point-ofcare detection and classification of direct-acting oral anticoagulants (DOACs) with the TEG(R) 6s: implications for trauma and acute care surgery. J Trauma Acute Care Surg 87:364-370

14. Ranucci M, Baryshnikova E, Soro G et al (2011) Multiple electrode whole-blood aggregometry and bleeding in cardiac surgery patients receiving thienopyridines. Ann Thorac Surg 91(1):123-129

15. Sibbing D, Braun S, Morath T et al (2009) Platelet reactivity after clopidogrel treatment assessed with point-of-care analysis and early drug-eluting stent thrombosis. J Am Coll Cardiol 53(10):849-856 
16. Sibbing D, Steinhubl SR, Schulz S, Schomig A, Kastrati A (2010) Platelet aggregation and its association with stent thrombosis and bleeding in clopidogrel-treated patients: initial evidence of a therapeutic window. J Am Coll Cardiol 56(4):317-318

17. Breet NJ, van Werkum JW, Bouman HJ et al (2011) High ontreatment platelet reactivity to both aspirin and clopidogrel is associated with the highest risk of adverse events following percutaneous coronary intervention. Heart 97(12):983-990

18. Price MJ, Endemann S, Gollapudi RR et al (2008) Prognostic significance of post-clopidogrel platelet reactivity assessed by a point-of-care assay on thrombotic events after drug-eluting stent implantation. Eur Heart J 29(8):992-1000

19. Paniccia R, Priora R, Liotta AA, Abbate R (2015) Platelet function tests: a comparative review. Vasc Health Risk Manag 11:133-148

20. Gurbel PA, Bliden KP, Tantry US et al (2016) First report of the point-of-care TEG: a technical validation study of the TEG-6S system. Platelets 27(7):642-649

21. Hartmann J, Mason D, Achneck H (2018) Thromboelastography (TEG) point-of-care diagnostic for hemostasis management. Point Care 17(1):15-22

22. Ramiz S, Hartmann J (2019) Clinical utility of viscoelastic testing (TEG and ROTEM analyzers) in the management of old and new therapies for hemophilia. Am J Hematol 94(2):249-256

23. Gremmel T, Steiner S, Seidinger D et al (2009) Comparison of methods to evaluate clopidogrel-mediated platelet inhibition after percutaneous intervention with stent implantation. Thromb Haemost 101(2):333-339

24. Paniccia R, Antonucci E, Maggini N et al (2009) Assessment of platelet function on whole blood by multiple electrode aggregometry in high-risk patients with coronary artery disease receiving antiplatelet therapy. Am J Clin Pathol 131(6):834-842

25. Sibbing D, Braun S, Jawansky S et al (2008) Assessment of ADPinduced platelet aggregation with light transmission aggregometry and multiple electrode platelet aggregometry before and after clopidogrel treatment. Thromb Haemost 99(1):121-126

26. Smith JW, Steinhubl SR, Lincoff AM et al (1999) Rapid plateletfunction assay: an automated and quantitative cartridge-based method. Circulation 99(5):620-625

27. Jakubowski JA, Payne CD, Li YG et al (2008) The use of the VerifyNow P2Y12 point-of-care device to monitor platelet function across a range of $\mathrm{P} 2 \mathrm{Y} 12$ inhibition levels following prasugrel and clopidogrel administration. Thromb Haemost 99(2):409-415

28. Paniccia R, Antonucci E, Gori AM et al (2007) Different methodologies for evaluating the effect of clopidogrel on platelet function in high-risk coronary artery disease patients. J Thromb Haemost 5(9):1839-1847

29. Cayla G, Cuisset T, Silvain J et al (2016) Platelet function monitoring to adjust antiplatelet therapy in elderly patients stented for an acute coronary syndrome (ANTARCTIC): an open-label, blinded-endpoint, randomised controlled superiority trial. Lancet 388(10055):2015-2022

30. Collet JP, Cuisset T, Range G et al (2012) Bedside monitoring to adjust antiplatelet therapy for coronary stenting. N Engl J Med 367(22):2100-2109

31. Siller-Matula JM, Jilma B (2013) Why have studies of tailored anti-platelet therapy failed so far? Thromb Haemost 110(4):628-631

32. Khanna V, Hobson A, Mikael R et al (2014) Does the VerifyNow P2Y12 assay overestimate "therapeutic response" to clopidogrel? Insights using short thrombelastography. Thromb Haemost 111(6):1150-1159

33. Danielak D, Komosa A, Tomczak A et al (2017) Determinants of high on-treatment platelet reactivity and agreement between VerifyNow and Multiplate assays. Scand J Clin Lab Invest 77(3):190-198

34. Collyer T, Gray D, Sandhu R, Berridge J, Lyons G (2009) Assessment of platelet inhibition secondary to clopidogrel and aspirin therapy in preoperative acute surgical patients measured by Thrombelastography ${ }^{\circledR}$ Platelet Mapping ${ }^{\mathrm{TM}}$. Br J Anaesth 102(4):492-498

35. Can MM, Tanboga IH, Turkyilmaz E et al (2010) The risk of false results in the assessment of platelet function in the absence of antiplatelet medication: comparison of the PFA-100, multiplate electrical impedance aggregometry and verify now assays. Thromb Res 125(4):e132-e137

36. Penz SM, Bernlochner I, Toth O et al (2010) Selective and rapid monitoring of dual platelet inhibition by aspirin and P2Y12 antagonists by using multiple electrode aggregometry. Thromb J 8:9

37. Ko YG, Suh JW, Kim BH et al (2011) Comparison of 2 pointof-care platelet function tests, VerifyNow Assay and Multiple Electrode Platelet Aggregometry, for predicting early clinical outcomes in patients undergoing percutaneous coronary intervention. Am Heart J 161(2):383-390

38. Larsen PD, Holley AS, Sasse A et al (2017) Comparison of Multiplate and VerifyNow platelet function tests in predicting clinical outcome in patients with acute coronary syndromes. Thromb Res 152:14-19

39. Calmette L, Martin AC, Le Bonniec B et al (2017) Ticagrelor reversal: in vitro assessment of four haemostatic agents. J Clin Pathol 70(9):733-739

Publisher's Note Springer Nature remains neutral with regard to jurisdictional claims in published maps and institutional affiliations. 